\title{
The effects of short-term culture and perifusion on LH-dependent steroidogenesis in isolated rat Leydig cells
}

\author{
F. F. G. Rommerts, M. J. A. van Roemburg, L. M. Lindh, J. A. J. Hegge \\ and H. J. van der Molen \\ Department of Biochemistry (Division of Chemical Endocrinology), Faculty of Medicine, \\ Erasmus University, Rotterdam, The Netherlands
}

\begin{abstract}
Summary. Tumour Leydig cells and normal mature Leydig cells lost their steroidogenic response (pregnenolone and testosterone secretion) to $\mathrm{LH}$ after $24 \mathrm{~h}$ of culture. Immature cells showed a 2 -fold increase in the basal pregnenolone secretion and no change in the LH-dependent pregnenolone secretion after $24 \mathrm{~h}$ of culture, whereas the LH-dependent steroidogenesis decreased after $48 \mathrm{~h}$. None of the 3 cell preparations showed morphological signs of degeneration during a culture period of more than 7 days. Histochemical $3 \beta$-hydroxysteroid dehydrogenase activity in isolated immature Leydig cells disappeared during the first 2 days of the culture period and re-appeared after 5-7 days. Testosterone production by mature Leydig cells decreased during the first hours after exposure to $\mathrm{LH}$, whereas pregnenolone secretion remained constant. From these results it was concluded that Leydig cells attached to plastic can be used for investigation of acute actions of LH on steroidogenesis. A perifusion technique for cells attached to plastic was developed and was applied to the kinetics of $\mathrm{LH}$ action on steroidogenesis in tumour and immature Leydig cells. The first stimulation of pregnenolone secretion occurred within $5 \mathrm{~min}$, but a full stimulation was only obtained after $20-30 \mathrm{~min}$. This was followed by a gradual decrease in the stimulated steroid secretion to $\sim 50 \%$ after $60 \mathrm{~min}$.
\end{abstract}

\section{Introduction}

Freshly isolated Leydig cells have frequently been used for investigations on the biochemical mechanism of acute actions of trophic hormones (Dufau et al., 1978; Purvis, Clausen \& Hansson, 1978; Cooke, Lindh, van der Molen, 1979a; Hall, Charponnier, Nakamura \& Gabbiani, 1979). Isolated cell suspensions have been used also after pretreatment with trophic hormones in vivo (Saez, Haour, Loras, Sanchez \& Cathiard, 1978; Dufau et al., 1979). However, the use of freshly isolated cells has some disadvantages. It is generally accepted that cell surface receptors may be damaged by the enzyme treatment during the isolation procedure and it has been reported for Leydig cells that preincubated and non-preincubated cells show functional differences (Cooke, Janszen, van Driel \& van der Molen, 1979c). A recovery period during culture following the isolation procedure seems to be required. Moreover, during the initial period of culture, viable cells may be separated from dead cells and subfractionated by selective attachment to the (coated) plastic surface of culture dishes (Campbell, 1979). Application of culture techniques may therefore improve the quality of the cell preparation which subsequently can be investigated under defined culture conditions. Several investigators have shown that 
primary cultures of cells after long-term culture may lose functional properties (Shin, 1967; Khatim \& O'Hare, 1976; O'Hare, Ellison \& Neville, 1978; Dufau et al., 1979). The purpose of the present investigations was to establish and evaluate conditions for maintaining Leydig cells functionally active for more than $24 \mathrm{~h}$, so that the benefits of the culture techniques predominate over the drawbacks.

\section{Materials and Methods}

Ovine luteinizing hormone (NIH-LH-S20;1.2 i.u./mg) was a gift from the Endocrinology Study Section, National Institutes of Health, Bethesda, Maryland, U.S.A. Cyanoketone (2 $\alpha$-cyano$4,4^{\prime}, 17 \alpha$-trimethyl-17 $\beta$-hydroxy-5-androsten-3-one), an inhibitor of 3 $\beta$-hydroxysteroid dehydrogenase activity, is a former product of Stirling-Winthrop, New York, U.S.A. SU-10603 (7-chloro-3,4-dihydro-2-(3-pyridyl)-1-(2H)-naphthalenone), an inhibitor of 17 $\alpha$-hydroxylase activity, was a gift from Ciba-Geigy, Basle, Switzerland. Epidermal growth factor was obtained from Collaborative Research, Waltham, Massachusetts, U.S.A. A $26 \%$ Ficoll solution was prepared by dissolving $26 \mathrm{~g}$ Ficoll in $25 \mathrm{ml}$ distilled water and $50 \mathrm{ml}$ Krebs-Ringer buffer without glucose (KRB) (Umbreit, Burris \& Stauffer, 1964). The volume was adjusted to $98 \mathrm{ml}$ with $\mathrm{KRB}$ and the solution was autoclaved and kept at room temperature under $5 \% \mathrm{CO}_{2}$. Before use, $2 \mathrm{ml}$ of $20 \%$ sterile bovine serum albumin were added and $\mathrm{CO}_{2}$ was administered until the $\mathrm{pH}$ was $6 \cdot 5$.

\section{Animals}

Male Wistar rats, substrain R-Amsterdam, were used. Adult, 13-17-week-old rats were used for isolation of Leydig cells from the testes and 10-12-week-old rats were used for implantation of Leydig cell tumour tissue as described by Cooke et al. (1979b), but with slight modifications. Small $(1 \times 1 \mathrm{~mm})$ tissue fragments were subcutaneously injected in the neck region of normal intact rats and sufficient tumour tissue could be isolated 4-6 weeks later. Rats aged 22-24 days were used for preparation of Leydig cells from immature testes. All animals were kept under controlled light $(14 \mathrm{~h}$ light $/ 24 \mathrm{~h})$ and temperature $\left(20-22^{\circ} \mathrm{C}\right)$ conditions.

\section{Isolation of Leydig cells}

All procedures were carried out under sterile conditions and with sterile solutions, glass and plastic ware, if cells were incubated for periods longer than $8 \mathrm{~h}$.

Isolation of immature and tumour Leydig cells. Decapsulated testes from 10-20 immature rats or approximately $500 \mathrm{mg}$ minced tumour tissue were incubated at $37^{\circ} \mathrm{C}$ in $50 \mathrm{ml}$ plastic

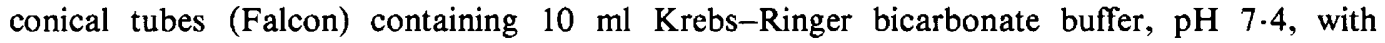
$0.2 \%$ glucose (KRBG) and $1 \mathrm{mg}$ collagenase (Worthington, $135 \mathrm{U} / \mathrm{mg}$ ) $/ \mathrm{ml}$.

The tubes were placed in a waterbath with their long axis parallel to the shaking direction and were shaken $(80 \mathrm{cycles} / \mathrm{min}$; amplitude $4 \mathrm{~cm}$ ). Incubation time was $20 \mathrm{~min}$ for testis tissue and 20-50 min for tumour tissue. The suspension was diluted with 10-30 ml KRBG and, after sedimentation of the tissue debris, the cell suspension was filtered through $60 \mu \mathrm{m}$ nylon gauze. The filtrate was centrifuged at $100 \mathrm{~g}$ for $10 \mathrm{~min}$ at room temperature. The supernatant was discarded and cells were resuspended in $2 \mathrm{ml} \mathrm{KRBG}$. The number of contaminating erythrocytes present in tumour cell preparations was reduced by removal of the top layer of the cell pellet after the centrifugation step and more than $10^{8}$ Leydig cells could be obtained from one tumour.

Isolation of mature Leydig cells. Cells were prepared as described previously by Janszen, Cooke, van Driel \& van der Molen (1976) with some modifications. The testes of mature rats were incubated for $5 \mathrm{~min}$ as described for immature testes and tumour tissue. Subsequently the 
medium (with erythrocytes) was renewed and the tissue was incubated another 15 min with fresh medium containing collagenase. The suspension was diluted with 10-30 ml KRBG and filtered through $60 \mu \mathrm{m}$ nylon gauze after sedimentation of the tubules. An equal amount of $26 \%$ Ficoll solution was added to the filtrate and the resulting cell suspension was centrifuged for $10 \mathrm{~min}$ at $1500 \mathrm{~g}$. The supernatant was discarded and the cells were resuspended in 2-3 $\mathrm{ml} \mathrm{KRBG}$.

\section{Incubation conditions}

Approximately $10^{6}$ cells were added to plastic Falcon dishes (diameter $35 \mathrm{~mm}$ ), containing 2 $\mathrm{ml}$ culture medium prepared from modified Eagle's medium with Earle's Liquid and non-essential amino-acids containing extra glutamin $(0.6 \mathrm{mg} / \mathrm{ml})$ and antibiotics $(100 \mathrm{U}$ penicillin $/ \mathrm{ml} ; 100 \mu \mathrm{g}$ streptomycin $/ \mathrm{ml}$ and $0.6 \mu \mathrm{g}$ Fungizone $/ \mathrm{ml}$ (Gibco)) with or without $1 \%$ fetal calf serum (Gibco). In some experiments cells were cultured in a 1:1 mixture of Ham's F12 nutrient mixture and Dulbecco's modified Eagle's medium (Gibco), supplemented with $1.2 \mathrm{~g}$ sodium carbonate/l, antibiotics, Fungizone, $5 \mu \mathrm{g}$ insulin $/ \mathrm{ml}, 5 \mu \mathrm{g}$ transferrin $/ \mathrm{ml}$ and $10 \mathrm{ng}$ epidermal growth factor $/ \mathrm{ml}$ (Collaborative Research) (Mather, 1980).

The cell suspension was incubated for $1 \mathrm{~h}$ at $37^{\circ} \mathrm{C}$ in standard medium with serum under $5 \%$ $\mathrm{CO}_{2}$ and $95 \%$ air. During this period most of the viable somatic cells attached to the plastic surface while the germinal cells and erythrocytes remained floating. After this preincubation period floating cells and weakly attached cells were removed by washing. Firmly attached cells were used for further experiments. A less selective attachment of cells occurred when cell suspensions were preincubated without serum. Attachment of all cell types to plastic or glass could be obtained after centrifugation of cell suspensions in medium without serum for a few minutes at $1000 \mathrm{~g}$.

During the first $24 \mathrm{~h}$ of culture the cells became flat and formed a monolayer which could be maintained for more than 7 days. Isolated tumour Leydig cells in culture showed mitotic activity during the first days.

\section{Hormone assays}

The steroidogenic activities of the Leydig cells were estimated by measuring the amounts of testosterone or pregnenolone secreted into the culture medium using radioimmunoassay methods as previously described (Verjans, Cooke, de Jong, de Jong \& van der Molen, 1973; van der Vusse, Kalkman \& van der Molen, 1975). Pregnenolone secretion was estimated in the presence of the inhibitors SU-10603 $\left(2 \times 10^{-5} \mathrm{M}\right)$ and cyanoketone $\left(5 \times 10^{-6} \mathrm{M}\right)$. Results from direct estimations in culture medium and from extracted samples were similar.

Steroidogenic activities in the Leydig cells were measured on the day of the cell preparation (Day 0 ) and during the next 2 days of the culture period (Days 1 and 2). The cells were used at the end of the experiment for protein analysis by the method of Lowry, Rosebrough, Farr \& Randall (1951) or for estimation of the $17 \alpha$-hydroxylase activity as described by Brinkmann, Leemborg, Roodnat, de Jong \& van der Molen (1980). Cells grown on object glasses were also used for histochemical detection of $3 \beta$-hydroxysteroid dehydrogenase (Janszen et al., 1976) and non-specific esterase (Rommerts, van Doorn, Galjaard, Cooke \& van der Molen, 1973).

\section{Perifusion of isolated cells}

A round disk (diameter $25 \mathrm{~mm}$ ) was cut from a plastic Petri dish with a warm cork bore. The disk was placed in a Petri dish and pressed to the bottom by a specially constructed hollow glass cylinder with an inner diameter slightly less than that of the disk. Approximately $10^{6}$ cells were applied to the disk via the glass cylinder. After a $1 \mathrm{~h}$ preincubation period in modified Eagle's medium with $1 \%$ fetal calf serum the glass cylinder was removed and the cells were washed 
extensively. The disk with attached cells was subsequently transferred to a slanted support plate made of brass, which was heated $\left(37^{\circ} \mathrm{C}\right)$ and could be rotated with a speed of $30 \mathrm{cycles} / \mathrm{min}$ (Text-fig. 1). A continuous supply of warm $\left(37^{\circ} \mathrm{C}\right)$ humid air containing $5 \% \mathrm{CO}_{2}$ was used to create an environment similar to that in the incubator. Culture medium was supplied from a syringe by an infusion pump with a rate of $\sim 0.2 \mathrm{ml} / \mathrm{min}$. Due to the slanted position of the plate, the rotation and the glass rod just above the disk, cells could be efficiently perifused with a dead volume of less than $150 \mu \mathrm{l}$. In the present experiments the medium was collected in $2.5 \mathrm{~min}$ fractions with a fraction collector.

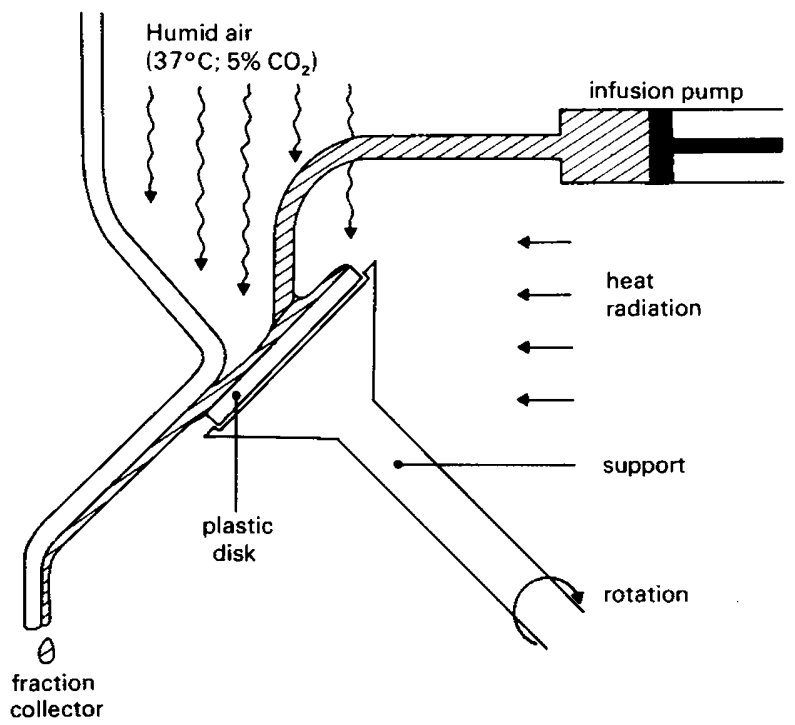

Text-fig. 1. Diagram of the perifusion system for isolated Leydig cells. The cells were attached to the plastic disk during a static incubation of $1 \mathrm{~h}$ at $37^{\circ} \mathrm{C}$. The disk + cells was placed on the brass support, which was heated at $37^{\circ} \mathrm{C}$ and rotated in a $37^{\circ} \mathrm{C}$ humid atmosphere containing $5 \% \mathrm{CO}_{2}$ and $95 \%$ air. Culture medium was supplied by an infusion pump. The medium was collected and transferred to the fraction collector with a glass rod. For further details see 'Materials and Methods'.

\section{Results}

\section{Steroidogenesis after short-term culture}

Leydig cell preparations prepared from tumour tissue, adult testes or immature testes were preincubated for $1 \mathrm{~h}$ at $37^{\circ} \mathrm{C}$ in culture medium containing $1 \%$ fetal calf serum, which caused a stimulation of $\sim 50 \%$ of the basal steroid production. Secretion of pregnenolone by the Leydig cell preparations was measured by incubating the cells in the presence of $1 \%$ fetal calf serum, firstly for $1 \mathrm{~h}$ without hormones, followed by $1 \mathrm{~h}$ incubation in the presence of a maximally stimulating dose of LH (for tumour, mature and immature Leydig cells 1000, 100 and 100 $\mathrm{ng} / \mathrm{ml}$, respectively). The pregnenolone secretion was increased more than 7 -fold by the LH additions. After $24 \mathrm{~h}$ incubation, tumour and adult Leydig cells had lost the LH-dependent steroidogenic response and showed only $7 \pm 4(n=5)$ and $8 \pm 8(n=6) \%$ (mean \pm s.d., $n=$ no. of cell preparations) of their respective activities at Day 0. Addition of dibutyryl-cAMP instead of LH or incubation of the cells in a mixture of Ham's F12 and Dulbecco-modified Eagle's medium, as described by Mather (1980), did not improve this. Leydig cells prepared from immature testes retained the capacity to respond to $\mathrm{LH}$. The secreted steroids apparently gave a 
good reflection of the total amount of steroids produced, because $9-13 \%$ of pregnenolone remained within the cells, irrespective of the concentration in the medium. These results suggest that under the present conditions Leydig cells from tumour tissue or adult testes can only be used for acute experiments, whereas immature Leydig cells can be used for experiments which last approximately $30 \mathrm{~h}$.

\section{Immature Leydig cells}

Basal and LH-stimulated secretion of pregnenolone was measured each day during culture (Table 1). The basal secretion of pregnenolone and the protein content increased approximately 2 -fold during the first $24 \mathrm{~h}$ of the culture period, while the maximal capacity for pregnenolone production, expressed per number of inoculated cells, remained constant. On the other hand, fluctuations in steroid production (reflecting fluctuations in the activities of the cells or the number of active cells in the different cell preparations) occurred. The dose-response curves to LH on Days 0 and 1 within one experiment were similar, except for an increase in the basal pregnenolone secretion on Day 1 (data not shown). However, the LH-dependent steroidogenic capacity was decreased on Day 2 (Table 1). Preincubation of the cells with LH for $24 \mathrm{~h}$ did not affect the LH-stimulated pregnenolone production on the next day.

Table 1. Change in protein content, basal and $\mathrm{LH}(100 \mathrm{ng} / \mathrm{ml})-$ stimulated secretion of pregnenolone by isolated Leydig cells from immature rats during culture

\begin{tabular}{|c|c|c|c|}
\hline \multirow{2}{*}{$\begin{array}{l}\text { Day of } \\
\text { culture }\end{array}$} & \multirow{2}{*}{$\begin{array}{c}\text { Protein } \\
\text { content } \\
\text { as } \% \\
\text { from Day } 0\end{array}$} & \multicolumn{2}{|c|}{ Pregnenolone $\left(\mathrm{ng} / \mathrm{mg}\right.$ protein. $\left.\mathrm{h}^{-1}\right)$} \\
\hline & & $-\mathrm{LH}$ & $+\mathrm{LH}$ \\
\hline 0 & 100 & $26 \pm 17$ & $267 \pm 127$ \\
\hline 1 & $201 \pm 34(4)^{*}$ & $45 \pm 24$ & $194 \pm 66 \quad(5) \dagger$ \\
\hline 2 & $217 \pm 34(4)^{*}$ & $5 \pm 2 \cdot 6(4)$ & $4 \cdot 7(4) \S$ \\
\hline
\end{tabular}

Values are mean \pm s.d. for the no. of cell preparations indicated, compared by paired Student's $t$ tests.

* $P<0.01$ when compared to the same condition at Day 0 .

$+P<0.01$ when compared to unstimulated cells at Day 1 .

$\ddagger P<0.05$ when compared to unstimulated cells at Day 0 .

$\S P<0.05$ when compared to LH-stimulated cells at Day 1.

Cultured Leydig cells did not show morphological signs of degeneration during culture periods lasting for more than 7 days. Histochemical detection of $3 \beta$-hydroxysteroid dehydrogenase activity $1 \mathrm{~h}$ after inoculation of the Leydig cell preparations showed $20-40 \%$ of the attached cells with a positive reaction. The enzyme activity was markedly decreased after 1 day of culture and could not be detected after 2 days. However, many active cells were again present in cultures maintained for 5-7 days without added LH.

\section{Mature Leydig cells}

Pregnenolone production by the attached cells was measured in medium containing inhibitors of pregnenolone metabolism; for estimation of testosterone secretion, medium without inhibitors was used. The culture media with the secreted steroids were isolated each hour and new culture medium was added (Text-fig. 2). Testosterone production during the third hour after 
LH administration was $41 \pm 6 \%$ of that during the first hour, whereas production of pregnenolone measured in another dish was not changed (110 $\pm 29 \%$; mean \pm s.d. from 5 independent cell preparations for both values). Further decreases in testosterone production occurred as the incubation period was extended. After $6 \mathrm{~h}$ 25-hydroxycholesterol was added to saturate the cholesterol side-chain cleavage enzyme (Text-fig. 2). Testosterone production was slightly increased but the secretion rate was still much less than during the first hour after LH. Pregnenolone secretion was unchanged or only slightly stimulated, indicating that the decreased testosterone production could not be attributed to cell losses during the incubation period. The changes which occur in the testosterone production can most clearly be demonstrated when the different amounts of steroid secreted per hour are shown individually. In a cumulative presentation, used frequently in kinetic studies with cell suspensions, the changes in the testosterone production were much less prominent (Text-fig. $2 \mathrm{c}$ ).

(a)
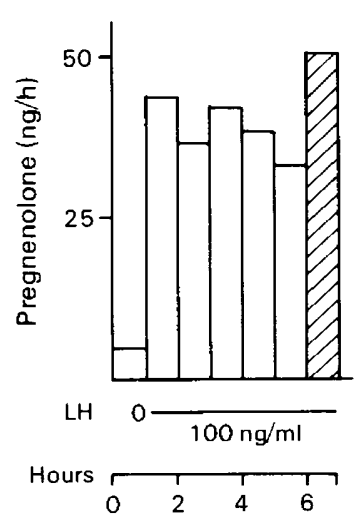

(b)

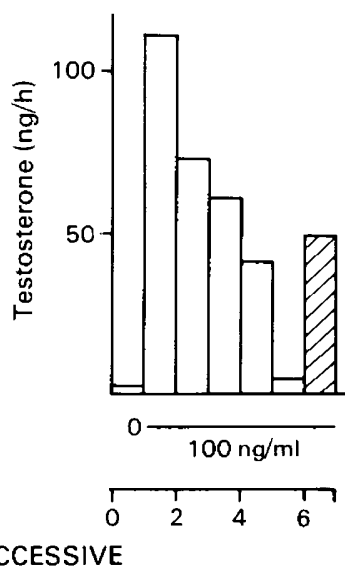

(c)

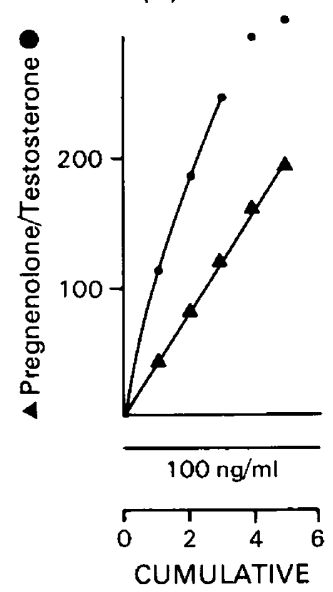

Text-fig. 2. Changes in secretion of (a) pregnenolone and (b) testosterone by mature Leydig cells attached to plastic dishes. Different portions of one cell preparation were incubated with (a) or without (b) inhibitors of pregnenolone metabolism and medium was collected and renewed each hour. LH was absent during the first hour and continuously present thereafter. Finally the cells were incubated in the presence of $\mathrm{LH}$ and $20 \mu \mathrm{M}$-25-hydroxycholesterol (hatched columns). (c) The values for the cumulative amount of secreted steroids were calculated from the results of the successive production during the different periods.

\section{Perifusion of Leydig cells}

The results from the perifusion studies are depicted in Text-fig. 3. The first change in steroid secretion following $\mathrm{LH}$ administration occurred within $5 \mathrm{~min}$ and an optimum was obtained after 20-30 min. A gradual decrease in the secretion of pregnenolone was observed when cells were continuously perifused with $\mathrm{LH}$. This decrease could not be attributed to appreciable detachment of cells from the plastic disk, because cell counts in the perifusion medium showed that at most $5 \%$ of the cells were removed. Moreover, rapid changes occurred within tumour cells during the in-vitro incubation without $\mathrm{LH}$; after incubation for $4 \mathrm{~h}$ the $17 \alpha$-hydroxylase activity was reduced to $11.8 \pm 1 \cdot 1 \%$ (s.d.; 3 different cell preparations) of the original activity. 


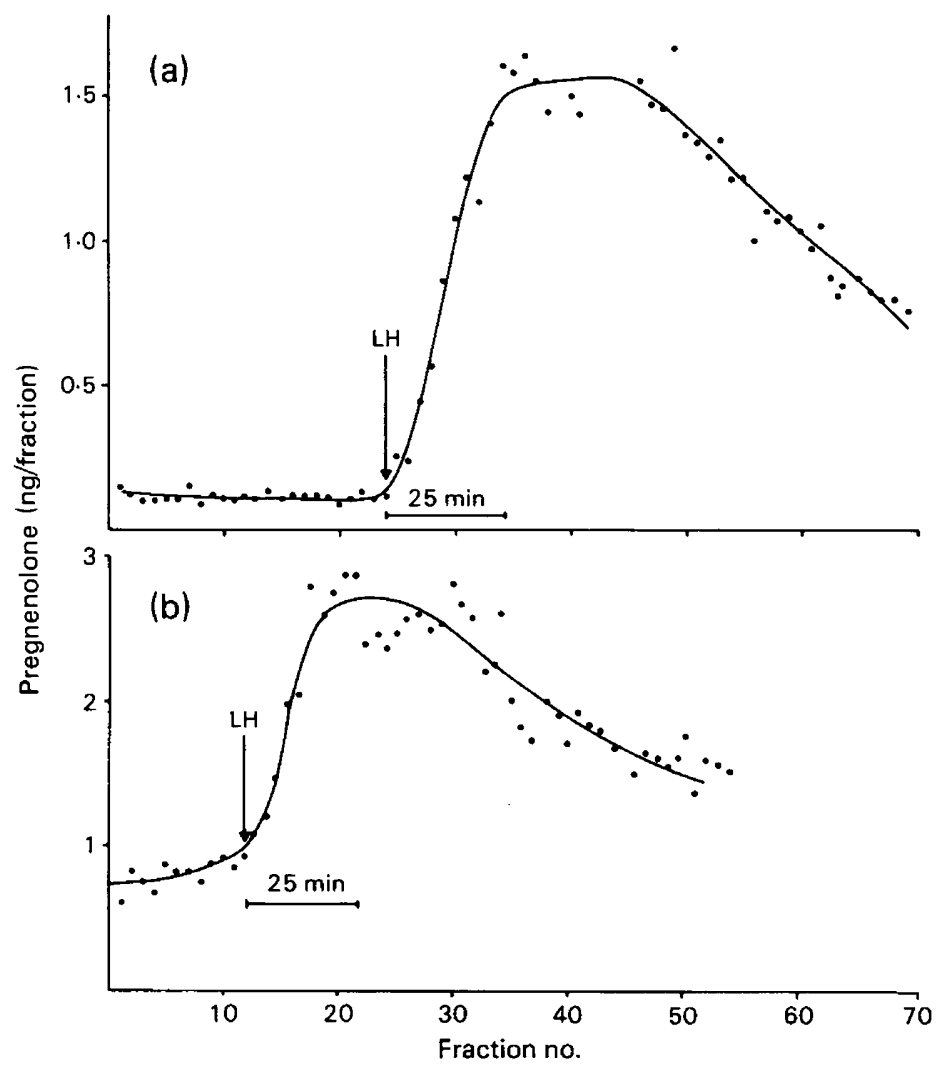

Text-fig. 3. Effect of LH on the secretion rate of pregnenolone by perifused rat Leydig cells from (a) immature testis and (b) tumour tissue. LH was continuously present after the first addition indicated by the arrow. For perifusion conditions see Text-fig. 1.

\section{Discussion}

Leydig cell fractions isolated from tumour tissue or mature or immature testes can attach to a plastic surface and remain viable for more than 7 days. However, during this culture period changes occur in the steroidogenic pathways leading to the biosynthesis of testosterone. In the present experiments LH-dependent pregnenolone production remained constant for approximately $6 \mathrm{~h}$ in all cell types and in immature Leydig cells for more than $24 \mathrm{~h}$, but a change in the metabolism of pregnenolone may occur in mature Leydig cells within $6 \mathrm{~h}$. Decreases in the rate of testosterone production or release, when compared to the initial rate, are also apparent in experiments described by Cigorraga, Dufau \& Catt (1978) and Cooke et al. (1979c). Several metabolites of pregnenolone have been detected in the culture medium of steroidogenic cells in culture (normal adult Leydig cells: Khatim \& O'Hare, 1976; Dufau et al., 1979; tumour Leydig cells: Shin, 1967; Inano, Tamaoki \& Tsubura, 1972; adrenal tumour cells: Saez, Morera \& Haour, 1979). The occurrence of these metabolites may suggest the absence or decreased activity of microsomal steroid $17 \alpha$-hydroxylase or steroid $C_{17-20}$-lyase. Changes in these microsomal enzymes may be caused by a decreased level of microsomal cytochrome $\mathrm{P}_{450}$ occurring within only a few hours after isolation and incubation of interstitial tissue (Purvis \& Menard, 1975). Similar changes in cytochrome $\mathrm{P}_{450}$ have been reported for isolated liver cells when exposed to an oxidizing environment (Bissell \& Guzelian, 1979). 
The rapid decline of the microsomal enzyme activities and the LH-dependent side-chain cleavage enzyme activity during the culture of the isolated rat Leydig cells may be a consequence of previous (physical) cell damage due to the isolation procedure or an (cell biological) adaptation of the cell to a new environment. The first explanation seems unlikely, because LH-dependent side-chain cleavage activity can be maintained in immature Leydig cells for more than $24 \mathrm{~h}$, but declines in tumour cells prepared under identical conditions. Moreover, the loss of the steroidogenic capacity in tumour Leydig cells occurs in cells which remain mitotically active for several days in culture. It seems, therefore, that the observed changes depend on inherent properties of the cells in culture. The latter conclusion is supported by the observation that after an initial loss of $3 \beta$-hydroxysteroid dehydrogenase activity the enzyme activity re-appears after 5-7 days of culture without LH. The absence of appreciable $3 \beta$-hydroxysteroid dehydrogenase activity after 1 day of culture in the presence of active and LH-dependent steroidogenesis represents a strong limitation of the use of this enzyme as a marker enzyme of active Leydig cells.

Measurement of pregnenolone formation seems most suitable for investigations of biochemical mechanisms of hormone action on steroidogenesis, because measurements are as close as possible to the rate-limiting step and the least influenced by the observed changes in the pregnenolone-converting enzymes. On the other hand, pregnenolone secretion is physiologically less meaningful. Superfusion techniques with isolated cells have been reported previously. Cells or tissue fragments have been packed in columns of glass beads (Cooke, Janszen, Clotscher \& van der Molen, 1975) or biogel (Lowry \& McMartin, 1974) or retained in suspension by balancing a flow of medium against an opposing centrifugal force (Schulster \& Jenner, 1975). With the present method, the properties of cells attached to a plastic surface can be compared under normal incubation conditions and under superfusion conditions.

Our study of the kinetics of $\mathrm{LH}$ action on steroidogenesis indicated a considerable difference in the times required for an initial response $(<5 \mathrm{~min})$ and a complete response $(20-30 \mathrm{~min})$. The gradual decrease in the secretion of pregnenolone during perifusion in the presence of $\mathrm{LH}$ cannot yet be explained. A similar phenomenon has been reported for testosterone production by tumour Leydig cells (Segaloff, Puett \& Ascoli, 1981) and normal adult Leydig cells (Davies \& Platzer, 1981) and suggestions have been made that the decline in the testosterone response is induced by the gonadotrophins. However, it could also be related to the specific perifusion conditions, because our results show that immature Leydig cells attached to plastic and incubated statically with $100 \mathrm{ng} \mathrm{LH}$ remain active in steroid production for more than $24 \mathrm{~h}$.

\section{References}

Bissell, D.M. \& Guzelian, P.S. (1979) Ascorbic acid deficiency and cytochrome P-450 in adult rat hepatocytes in primary monolayer culture. Archs Biochem. Biophys. 192, 569-576.

Brinkmann, A.O., Leemborg, G.G., Roodnat, E.M., de Jong, F.H. \& van der Molen, H.J. (1980) A specific action of estradiol on enzymes involved in testicular steroidogenesis. Biol. Reprod. 23, 801-809.

Campbell, G.L. (1979) An immunological approach to cell separation of the central nervous system. Fedn Proc. Fedn Am. Socs exp. Biol. 38, 2386-2390.

Cigorraga, S.B., Dufau, M.L. \& Catt, K.J. (1978) Regulation of luteinizing hormone receptors and steroidogenesis in gonadotropin-desensitized Leydig cells. J. biol. Chem. 253, 4297-4304.

Cooke, B.A., Janszen, F.H.A., Clotscher, W.F. \& van der Molen, H.J. (1975) Effect of protein synthesis inhibitors on testosterone production in rat testis interstitial tissue and Leydig cell preparations. Biochem. J. 150, 413-418.

Cooke, B.A., Lindh, L.M. \& van der Molen, H.J. (1979a) The mechanism of action of lutropin on regulator protein(s) involved in Leydig-cell steroidogenesis. Biochem. J. 184, 33-38.

Cooke, B.A., Lindh, L.M., Janszen, F.H.A., van Driel, M.J.A., Bakker, C.P., van der Plank, M.P.I. \& van der Molen, H.J. (1979b) A Leydig cell tumour. A model for the study of lutropin action. Biochim. biophys. Acta 583, 320-331.

Cooke, B.A., Janszen, F.H.A., van Driel, M.J.A. \& van der Molen, H.J. (1979c) Evidence for the involvement of lutropin-independent RNA synthesis in Leydig cell steroidogenesis. Molec. cell. Endocr. 14, 181-189. 
Davies, T.F. \& Platzer, M. (1981) The perifused Leydig cell: system characterization and rapid gonadotropin-induced desensitization. Endocrinology 108, 1757-1762.

Dufau, M.L., Horner, K.A., Hayashi, K., Tsuruhara, T., Conn, P.M. \& Catt, K.J. (1978) Actions of choleragen and gonadotropin in isolated Leydig cells. J. biol. Chem., 253, 3721-3729.

Dufau, M.L., Cigorraga, S.B., Baukal, A.J., Bator, J.M., Sorrell, S.H., Neubauer, J.F. \& Catt, K.J. (1979) Steroid biosynthetic lesions in gonadotropindesensitized Leydig cells. J. Steroid Biochem. 11, 193-199.

Hall, P.F., Charponnier, C., Nakamura, M. \& Gabbiani, G. (1979) The role of microfilaments in the response of Leydig cells to luteinizing hormone. J. Steroid Biochem. 11, 1361-1366.

Inano, H., Tamaoki, B.-I. \& Tsubura, Y. (1972) Steroid biosynthesis in vitro by transplantable interstitial cell tumor of mice. III. Metabolism of pregnenolone in the cultured tumor cell. Endocrinology 90, 307-310.

Janszen, F.H.A., Cooke, B.A., van Driel, M.J.A. \& van der Molen, H.J. (1976) Purification and characterization of Leydig cells from rat testes. J. Endocr. 70, 345-359.

Khatim, M.S. \& O'Hare, M.J. (1976) Testosterone and progesterone secretion by adult rat testis interstitial cells in monolayer culture. J. Endocr. 69, 19P-20P.

Lowry, O.H., Rosebrough, N.J., Farr, A.L. \& Randall, R.J. (1951) Protein measurement with the Folin phenol reagent. J. biol. Chem. 193, 265-275.

Lowry, P.J. \& McMartin, C. (1974) Measurement of stimulation and inhibition of steroidogenesis in isolated rat adrenal cells by column perifusion. Biochem. J. 142, 287-291.

Mather, J.P. (1980) Establishment and characterization of two distinct mouse testicular epithelial cell lines. Biol. Reprod. 23, 243-252.

O'Hare, M.J., Ellison, M.L. \& Neville, A.M. (1978) Tissue culture in endocrine research: perspectives, pit falls and potentials. In Current Topics in Experimental Endocrinology, Vol. 3, pp. 1-56. Eds L. Martini \& V. H. T. James. Academic Press, New York.

Purvis, J.L. \& Menard, R.H. (1975) Compartmentation of microsomal cytochrome P-450 and $17 \alpha-$ hydroxylase activity in the rat testis. In Hormonal Regulation of Spermatogenesis, pp. 65-84. Eds F. S.
French, V. Hansson, E. M. Ritzén \& S. N. Nayfeh. Plenum Press, New York.

Purvis, K., Clausen, O.P.F. \& Hansson, V. (1978) Age-related changes in responsiveness of rat Leydig cells to hCG. J. Reprod. Fert. 52, 379-386.

Rommerts, F.F.G., van Doorn, L.G., Galjaard, H., Cooke, B.A. \& van der Molen, H.J. (1973) Dissection of wet tissue and freeze-dried sections in the investigation of seminiferous tubules and interstitial tissue from rat testis. J. Histochem. Cytochem. 21, 572-579.

Saez, J.M., Haour, F., Loras, B., Sanchez, P. \& Cathiard, A.M. (1978) Oestrogen induced Leydig cell refractoriness to gonadotrophin stimulation. Acta endocr., Copenh. 89, 379-392.

Saez, J.M., Morera, A.M. \& Haour, F. (1979) Hormonal-induced refractoriness of steroidogenesis in testicular and adrenal cells. In Hormones and Cell Regulation, vol. 3, pp. 187-216. Eds J. Dumont \& J. Nunez. North-Holland, Amsterdam.

Schulster, D. \& Jenner, C. (1975) A counter-streaming centrifugation technique for the superfusion of adrenocortical cell suspensions stimulated by ACTH. J. Steroid Biochem. 6, 389-394.

Segaloff, D.L., Puett, D. \& Ascoli, M. (1981) The dynamics of the steroidogenic response of perifused Leydig tumour cells to human chorionic gonadotropin, ovine luteinizing hormone, cholera toxin and adenosine-3',5'-cyclic monophosphate. Endocrinology 108, 632-638.

Shin, S.-1. (1967) Studies on interstitial cells in tissue culture: steroid biosynthesis in monolayers of mouse testicular interstitial cells. Endocrinology 81, 440448.

Umbreit, W.W., Burris, R.H. \& Stauffer, J.F. (1964) Manometric Techniques, 4th edn, p. 132. Burgess Publ. Co., Minnesota.

van der Vusse, G.J., Kalkman, M.L. \& van der Molen, H.J. (1975) Endogenous steroid production in cellular and subcellular fractions of rat testis after prolonged treatment with gonadotropins. Biochim. Biophys. Acta 380, 473-485.

Verjans, H.L., Cooke, B.A., de Jong, F.H., de Jong, C.C. \& van der Molen, H.J. (1973) Evaluation of a radioimmunoassay for testosterone estimation. $J$. Steroid Biochem. 4, 665-676. 